\title{
The role of social media in communicating CSR within fashion micro-organizations
}

\section{Document Version}

Accepted author manuscript

Link to publication record in Manchester Research Explorer

\section{Citation for published version (APA):}

Henninger, C. E., \& Oates, C. J. (Accepted/In press). The role of social media in communicating CSR within fashion micro-organizations. In The Use and Effectivness of CSR Communications through Digital Platforms Gower Publishing Ltd.

\section{Published in:}

The Use and Effectivness of CSR Communications through Digital Platforms

\section{Citing this paper}

Please note that where the full-text provided on Manchester Research Explorer is the Author Accepted Manuscript or Proof version this may differ from the final Published version. If citing, it is advised that you check and use the publisher's definitive version.

\section{General rights}

Copyright and moral rights for the publications made accessible in the Research Explorer are retained by the authors and/or other copyright owners and it is a condition of accessing publications that users recognise and abide by the legal requirements associated with these rights.

\section{Takedown policy}

If you believe that this document breaches copyright please refer to the University of Manchester's Takedown Procedures [http://man.ac.uk/04Y6Bo] or contact uml.scholarlycommunications@manchester.ac.uk providing relevant details, so we can investigate your claim.

\section{OPEN ACCESS}


Claudia E. Henninger \& Caroline J Oates (2017) The role of social media in communicating CSR within fashion micro-organizations. In Adam Lindgreen, Joelle Vanhamme, Francois Maon, \& Rebecca Watkins (eds) The Use and Effectivness of CSR Communications through Digital Platforms, Gower: Farnham

\title{
The role of social media in communicating CSR within fashion micro- organizations
}

\begin{abstract}
This chapter investigates how sustainable fashion micro-organizations understand and communicate CSR activities through their digital platforms, focusing specifically on social media, such as Twitter, Facebook, and blogs. A qualitative research methodology based on semi-structured interviews, semiotics, and Twitterfeed analysis provides an insight into three micro-organizations. The findings suggest that although social media plays an increasingly important role in promoting a company's products and services, not all platforms may be appropriate to communicate CSR activities. Blogs emerge as valuable tools to gain stakeholder engagement, which allow organizations to actively communicate their CSR activities to a wider audience.
\end{abstract}

\section{Keywords}

CSR, social media, Twitter, Facebook, blog, micro-organizations, communication

\section{Introduction}

The collapse of the Rana Plaza factory in 2013 - one of the biggest fashion industry accidents in history in which thousands of people died ${ }^{1}$ - saw a noticeable increase in corporate social responsibility (CSR) polices introduced by clothing manufacturers, seeking to make a difference in current production practices ${ }^{2,3}$. The negative media received by the fashion industry raised public awareness and knowledge of the social and environmental impacts that garments and textiles have on the natural environment and led to consumers demanding changes to be made. This resulted in an increase in CSR activities from the organizations' side, as a direct response to consumers wanting more 'sustainable' actions to be implemented across the supply chain and production 
process ${ }^{4,5}$. CSR can be defined as "a concept whereby companies integrate social and environmental concerns in their business operations and in their interaction with stakeholders on a voluntary basis" (p.5). It seeks to "achiev[e] commercial success in ways that honor ethical values and respect people, communities, and the natural environment" (p.6). CSR provides organizations with the opportunity to legitimize their economic actions, whilst at the same time showing their environmental and social responsibility to a wider audience ${ }^{8}$.

This chapter focuses on three 'sustainable' fashion micro-organizations that are heavily involved in a variety of CSR activities. Micro-organizations employ fewer than 10 employees, are dependent on their owner-manager, are vulnerable to increased competition, and have a limited financial budget ${ }^{9}$. Hence, online communication channels become increasingly important as the limited finances of these micro-organizations encourage utilization of new, free digital platforms, such as Twitter and Facebook to broadcast a company's CSR messages to a wider audience.

Past research on CSR has predominantly focused on large organizations and only more recently on small- and medium-sized enterprises (SMEs), which still excludes micro-organizations ${ }^{10}$. Yet within the fashion industry, which contributes $226 \mathrm{bn}$ to the UK economy ${ }^{11}$ micro-organizations dominate the business landscape with new designers and brands emerging almost daily. Such organizations contribute $34.9 \%$ of private sector turnover and account for over $32 \%$ of employment in the $\mathrm{UK}^{12}$. The importance of microorganizations as key economic drivers further justifies this research, which explores three research questions:

1) What does CSR mean in micro-organizations;

2) How do micro-organizations communicate their CSR initiatives to their stakeholders (customers, suppliers, and consumers);

3) What role does social media play within the process of communicating CSR initiatives.

\section{Literature Review}

\section{CSR - Definitions}

Industrial disasters in the fashion industry (e.g. Rana Plaza) have put garment manufacturers in the spotlight and challenged their legitimacy of providing products/services that not only fulfill the needs of the current generation, but also allow 
for future generations to cater for their needs/wants ${ }^{13,14}$. In order to counteract poor publicity, more and more fashion organizations emerge that have CSR activities at the core of their business strategy. Toms Shoes, for example, provide a free pair of shoes to a child in need with every consumer purchase from any of their product ranges, whilst H\&M utilizes organic materials in their conscious-line collection, thereby promoting worker safety in handling their raw materials and the payment of living wages ${ }^{15,16}$. For micro-organizations, which have a limited budget, and potentially lack business and marketing experience, creating successful CSR activities can be challenging. The extent of their activities will be on a smaller scale compared to that of large or multinational companies, yet it is vital that any organization that wants to be perceived as socially and environmentally responsible matches its stakeholders' expectations ${ }^{17}$. Such expectations can be managed through active communication that supports the organizations' activities and encourages stakeholder engagement ${ }^{18,19}$. It is implied that the magnitude of the CSR activity of an organization is almost irrelevant - as long as the company is actively involved in CSR activities that are clearly communicated to stakeholders and meet their expectations, stakeholders will have a positive image of the brand ${ }^{20}$.

CSR activity is not a new phenomenon, but has received additional attention after factory incidents in Asia created a bleak backdrop to the fashion industry as a whole. CSR is part of the 'sustainability movement', which has emerged as a 'megatrend' ${ }^{21}$ and focuses predominantly on the social aspect of sustainability. CSR has a broad variety of meanings and in this chapter we start from an understanding of CSR as "actions that appear to further some social good, beyond the interest of the firm and that which is required by law"22 (p.117). This definition has been used by previous researchers to investigate the motivational drivers underpinning CSR activities can be characterized as moral obligation, sustainability, license to operate, and reputation ${ }^{23,24}$. Moral obligation suggests being a 'good corporate citizen',25, which links to sustainability, and establishing and maintaining long-term relationships with the community and other stakeholders. A license to operate is concerned with legal requirements introduced by governments and 'forced upon' organizations to act more responsibly. Examples could be labor laws that clearly highlight minimum wage requirements, age restrictions of workers, and/or the use of chemicals in dyes. Last, reputation as a motivational driver focuses on creating 
stakeholder buy-in internally and externally. Community based activities, such as fundraisers or the establishment of leisure and educational facilities are examples of this category. Whilst "no business can solve all of society's problems or bear the cost of doing so... each company must select issues that intersect with its particular business"26 (p.9). Thus, an organization privileges issues of importance, which can be thought of in three different but related ways according to society and the environment ${ }^{27,28}$ : i) issues that are important to society, but do not affect a company's business; ii) a focus on the value chain and thus, issues that impact on the product lifecycle; or iii) issues that effect competitive drivers within a market place.

Although CSR has been criticized as a tool that promotes the agenda of individual organizations, the government, and non-governmental organizations (NGOs), it can also be seen as an important initiative that can attract skilled workers to an organization and improve a company's overall reputation ${ }^{29}$. In today's society having a favorable reputation is more important than ever and companies need to continually adapt to consumer demands and expectations ${ }^{30}$. Technological advancements have led to increased fragmentation of communication channels and the emergence of social media platforms, such as Twitter and Facebook ${ }^{31,32}$. It is no longer enough simply to have a CSR strategy, but rather it has to be clearly communicated across multiple channels ${ }^{33}$. Stakeholders play an increasingly important role, as they are no longer silent recipients of a message - through social media they have the ability to actively communicate with organizations and be part of their (organizations') CSR conversation. This provides both opportunities and challenges for organizations, which need to be researched further utilizing non-traditional research methods to understand how and what organizations share with and communicate to their audiences ${ }^{34}$.

\section{CSR and Social Media}

The emergence of Web2.0 has changed the communication landscape for CSR activities by allowing stakeholders to play an active role in the communication process. Web2.0 is defined as "the philosophy of mutually maximizing collective intelligence and added value for each participant by formalized and dynamic information sharing and creation",35 (p.12). Stakeholders now have the opportunity, if they desire, to actively engage in the 
creation and evaluation of content established by organizations and express their concerns directly. Ideally, this leads to co-creation processes in which both stakeholders and organizations mutually benefit ${ }^{36}$. Research suggests that organizations "need to engage with stakeholders as they have the power (...) to influence the achievement of outcomes" $^{37}$ (p.56). Through interactive communication stakeholders are empowered and gain the opportunity to voice their opinion, whilst organizations can implement changes to create a reputation that is positively perceived by their stakeholders ${ }^{38}$.

Social media has emerged as part of Web2.0 reshaping the previously existing dynamics in communication between stakeholders and organizations from a one-way process towards dialogic communication ${ }^{39,40}$. Social media has received attention within the academic literature and is seen as a necessary information channel to distribute brand messages and raise stakeholder awareness of an organization's CSR activities ${ }^{41}$. Real time communication tools (e.g. Twitter, Facebook) allow for instant sharing of messages, which can be seen by 'followers' (Twitter) and 'friends' (Facebook), thereby reaching a wide audience in real time ${ }^{42}$. Social media provides a broad range of opportunities for organizations to not only involve stakeholders and the general public in CSR debates, but also to raise awareness about issues within the industry ${ }^{43,44}$. Lee et $a l^{45}$ insist that it is "imperative for firms to successfully integrate new media into their extant communication strategy" (p.792). A key challenge associated with social media is the lack of control over any messages that are shared, liked, and re-posted. Stakeholders can search on a multitude of pages and channels and gain access to information organizations were previously able to 'hide ${ }^{, 46,47}$.

With social media gaining popularity and providing an opportunity for microorganizations to broadcast their message to a wider audience at a small or no cost, understanding how and what to communicate becomes a key issue that needs careful consideration. This chapter contributes to knowledge by focusing on an under-researched area (micro-organizations) and filling a gap to utilize innovative sources of research data to explore CSR communication in the $21^{\text {st }}$ century ${ }^{48}$.

\section{Methodology}

This chapter utilizes an interpretivist research philosophy and is qualitative in nature. The 
aim of this chapter is to explore in how far micro-organizations communicate their CSR practices through their various digital platforms, specifically social media accounts (e.g. Twitter, Facebook). Due to the nature of this research, which seeks to understand a complex phenomenon within its real life context a case study approach was deemed appropriate $^{49}$. Case study research allowed for multiple qualitative methodological tools to be utilized, such as in-depth semi-structured interviews, semiotics, and social media analysis.

The three micro-organizations were purposive selected to best answer the research questions. Requirements for their recruitment included: first, they are classified as micro$\operatorname{organizations}^{50}$; second, operate in the UK fashion industry; third, have sustainability at their core; and fourth, self-proclaim 'CSR activities'. Although similar in nature, these micro-organizations differ in size and years of operation (Table 1).

Table 1: Data summary (authors' own creation)

\begin{tabular}{|c|c|c|c|}
\hline & Organization 1 & Organization 2 & Organization 3 \\
\hline Description & $\begin{array}{l}\text { - Est. } 2007 \\
\text { - Women's fashion } \\
\text { - Upcyling/recycling } \\
\text { techniques }\end{array}$ & $\begin{array}{l}\text { - Est. } 2002 \\
\text { - Children's wear } \\
\text { - Sources in EU }\end{array}$ & $\begin{array}{l}\text { Est. } 2012 \\
\text { High-end to vintage } \\
\text { fashion }\end{array}$ \\
\hline $\begin{array}{c}\text { No. of } \\
\text { interviews } \\
\text { (Is) } \\
\end{array}$ & 5 & 6 & 7 \\
\hline $\begin{array}{c}\text { Interview } \\
\text { duration }\end{array}$ & $13: 33-57: 22 \mathrm{~min}$ & 10:00-60:00min & $7: 51-45: 35 \mathrm{~min}$ \\
\hline $\begin{array}{c}\text { Interviewee } \\
\text { Profile }\end{array}$ & $\begin{array}{l}\text { - O/M1, founder } \\
\cdot \text { Head of IT, joined } \\
\text { in } 2008 \\
\cdot \text { Seamstress, joined } \\
\text { in } 2010 \\
\cdot \text { Apprentice, joined } \\
\text { in } 2014 \\
\cdot \text { Workshop lead, } \\
\text { joined in } 2009\end{array}$ & $\begin{array}{l}\text { - O/M2, founder } \\
\text { - Seamstress original } \\
\text { member of company } \\
\text { - Seamstress, joined in } \\
2006, \text { part-time } \\
\text { - Seamstress, joined in } \\
2012 \\
\text { - Production manager, } \\
\text { original member of } \\
\text { company } \\
\text { - Quality manager, } \\
\text { joined in } 2013\end{array}$ & $\begin{array}{l}\text { O/M3, founder } \\
\text { Designer, own business } \\
\text { since } 2006, \text { joined co- } \\
\text { operative in } 2012 \\
\cdot \text { Designer, own business } \\
\text { since } 2001, \text { joined co- } \\
\text { operative in } 2012 \\
\text { - Designer, own business } \\
\text { since } 2010 \text {, joined co- } \\
\text { operative in } 2012 \\
\text { Employee, joined in } \\
2013 \\
\text { - Seamstress/designer, } \\
\text { joined } 2012\end{array}$ \\
\hline $\begin{array}{c}\text { Twitterfeed } \\
\text { (TF) }\end{array}$ & \multicolumn{3}{|c|}{$\checkmark$} \\
\hline $\begin{array}{c}\text { Semiotics } \\
\text { (SE) }\end{array}$ & \multicolumn{3}{|c|}{ Website; Blog; Newsletter; Email; Photographs; Garment-tags } \\
\hline
\end{tabular}


The exploratory research in each of the micro-organization was conducted over a three month period, which resulted in rich data sets. The analysis took several months, in which we iteratively coded data sets up to five times. To guarantee rigor and reliability Easterby-Smith et al's ${ }^{51}$ seven step guide was utilized, which allowed for familiarization with and reflection on the data, conceptualizing and cataloguing of emerging themes, recoding of the data, linking emerging themes, and re-evaluating the findings. Due to the interpretivist nature of this research it was seen as vital that themes could emerge naturally, whilst at the same time could be contrasted and compared. We discussed emerging themes in regular meetings and made sure any discrepancies were re-analyzed. The results were presented to the participants for validation purposes.

It could be argued that the sample and the size of this research act as a limitation, as the context is highly specific: micro-organizations operating in the UK's fashion industry. However, this provides an opportunity to explore an under researched field, the creative and cultural industries ${ }^{52}$, whilst at the same time purposefully investigating a sector that is of great economic importance ${ }^{53}$. We do not seek to provide any generalizable results, but rather bring forward learning points that can be addressed in future research.

\section{Findings}

\section{The meaning of CSR in micro-organizations}

These micro-organizations believe that their production processes, sourcing and manufacturing techniques, as well as their end-of-life garment treatment workshops are activities that support their CSR policies and sustainability measures in more general terms. Figure 1 provides a basic blueprint of these micro-organizations clearly showcasing the individual steps in the decision-making process of constructing a garment, which starts from the design process, choice of material, sourcing of materials, the production of the collection, the finished product, distribution, purchase by the customer, and the end-of-life treatment of the discarded items. These micro-organizations were established with aspects of sustainability in mind in that they seek to reduce the impact their collections have on the natural and social environment. 
Figure 1: Blueprint of micro-organizations (authors' own creation

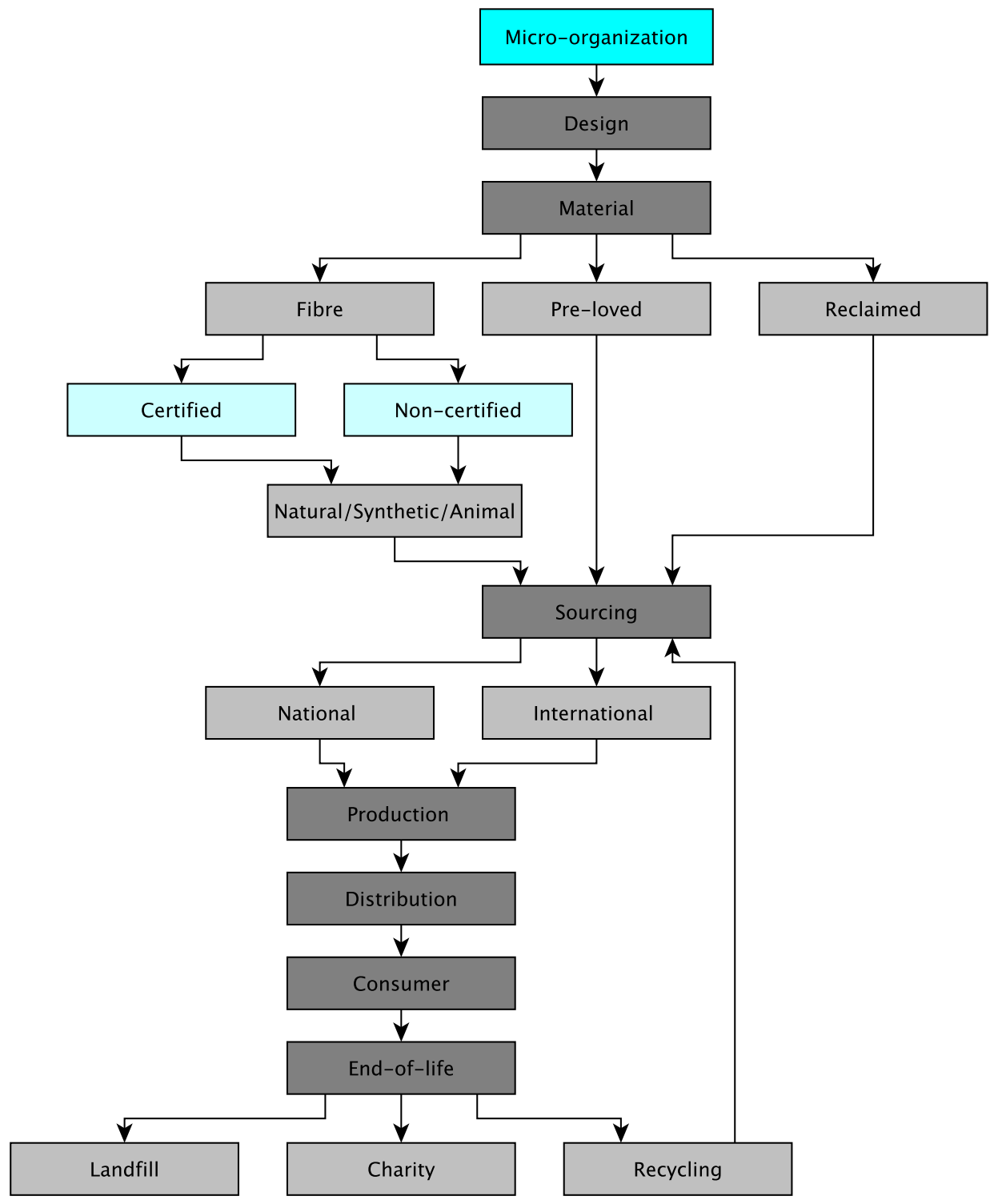

The introduction highlighted that research on micro-organizations is limited ${ }^{54}$. When we engaged with these three fashion micro-organizations, we wanted to understand how the owner-managers and their employees interpret CSR activities. OM1 states that she has been actively involved in the community and seeks to incorporate local creative talents into her business. For her, CSR implies providing people with an opportunity to 
develop their skills further and having a creativity outlet. She insists that "without me it'd just be a collection of people making things and selling them on market stalls... my role really is to take everything away from a village hall craft aesthetic... I feel a bit like it's a massive jigsaw puzzle and I'm in the middle slotting the bits together" (OM1 Is). From the interview it becomes apparent that for OM1 creating jobs is an essential part of CSR activities, as providing local people and design/fashion students with work experience and volunteer opportunities are key parts of her definition. An employee supports this view explaining that OM1 "employs everyone that she can, like a little local hat maker and a little lady doing crochet collars... she really encourages local makers and doers to keep up and makes use of their skills" (Employee Is). Although the owner-manager's definition fits the McWilliams and Siegel ${ }^{55}$ CSR interpretation, the employee's elaboration somewhat contradicts this definition, as CSR is not interpreted as solely doing good within society beyond the interest of the firm and regulations ${ }^{56}$. Even though creating jobs and other opportunities within the local community can be seen as a CSR activity, doing this to gain benefits for the micro-organization in the form of profit does not fit the interpretation of CSR. Thus, their definition of CSR links more closely with the interpretation of stakeholder engagement, whereby stakeholders (e.g. employees, community) are seen as a source of opportunity to further the overall business ${ }^{57}$.

OM2 similarly feels that providing employment in the community is an essential part of doing business and showing to be a 'good corporate citizen' ${ }^{58}$. However, OM2 believes that it is her responsibility to go beyond simply providing opportunities locally. In accordance with her product range of children's fashion, she set up a partnership in 2012 with an international agency that supports children in need by donating a certain percentage of her organization's annual profits, which funds educational programs (SE). To ensure that the money reaches the end-destination, she also undertakes regular trips to the site in Cambodia and supports the agency in their work. OM2's interpretation of CSR activities concurs with various authors ${ }^{59,60}$, who classify CSR activities as a moral obligation and a license to operate. Employees indicate that they feel proud to be part of the micro-organization and support their owner-manager where they can.

Micro-organization 3 differs slightly from micro-organizations 1 and 2 in that it is a co-operative that is managed by a single individual. OM3 states that for her CSR 
implies "being part of the community" (Is). OM3 opened her shop with support from the Mary Portas fund and the local council. The money received provides her with the opportunity to fund four apprentices, who gain work experience, whilst running the store. OM3 encourages designers to bring forward ideas to raise awareness for the shop. Past activities could be classified as being CSR related, as they involved a fundraiser to support rebuilding parts of the local cathedral (Is; SE). Throughout the research process it became apparent that OM3 believes any activity that involves the local community can be classified as CSR, as "you are making an effort and do social things that people like" (Is). Yet, it seems that these activities are organized as part of an ulterior motive: to raise awareness for the store and get people to shop in their premises, rather than solely to do good. Thus, CSR activities are seen as an opportunity to create a positive buzz for the organization that ideally leads to good publicity.

When discussing aspects of CSR with the owner-managers and the employees, employment opportunities and community involvement were mentioned first, before focusing on the fact that they produce within the UK, source locally - where possible and organize workshops for the general public to learn about issues of sustainability. For example, all of the organizations offer either upcycling and recycling workshops that support people's creativity and educate them on aspects of sustainability (as understood by the owner-manager) (Organizations 1 and 3) or provide apprenticeships that are based on keeping British heritage alive through teaching young adults the craft of sewing (Organization 2).

A commonality between the interpretations is the fact that employment and giving people an opportunity to express their creativity are essential parts of CSR. Only one out of the three companies insists that CSR activities need to go further, by either reinvesting money or donating it to a company related good cause. Underlying all of these CSR activities is the need to increase company awareness and ideally raise profits. This implies that contrary to McWilliams and Siegel's ${ }^{61}$ definition that sees CSR as a selfless act to do good, these micro-organizations interpret CSR as a way to advertise their companies and gain recognition in the community, with the aim of promoting their brand and selling products. On the other hand, aspects of sourcing, production techniques, and the actual raw materials are believed to be essential for the business, which links to 
aspects of sustainability.

\section{CSR communication to stakeholders}

Understanding how these micro-organizations interpret CSR is a vital first step in analyzing what channels are used to communicate these activities and in how far these reach the intended audience. All members of these micro-organizations concur that online communication is "the way forward, of course" (OM2 Is). Due to the acknowledged lack of financial resources social media channels are seen as key tools to stay in touch with stakeholders and bring forward their organizations' messages. An employee (microorganization 1) states that "one of the things we do more of ... is getting people online more involved in us and what we do and how we do it and all the interesting stuff different people that work in the studio are part of... 'cause people like to know things" (Is). Thus, digital channels are seen as promotional tools to promote the brand to stakeholders, thereby re-emphasizing their brand's values. Figure 2 provides an overview of the communication channels identified in these micro-organizations. We focus on social media and online channels only.

Figure 2: Communication channels

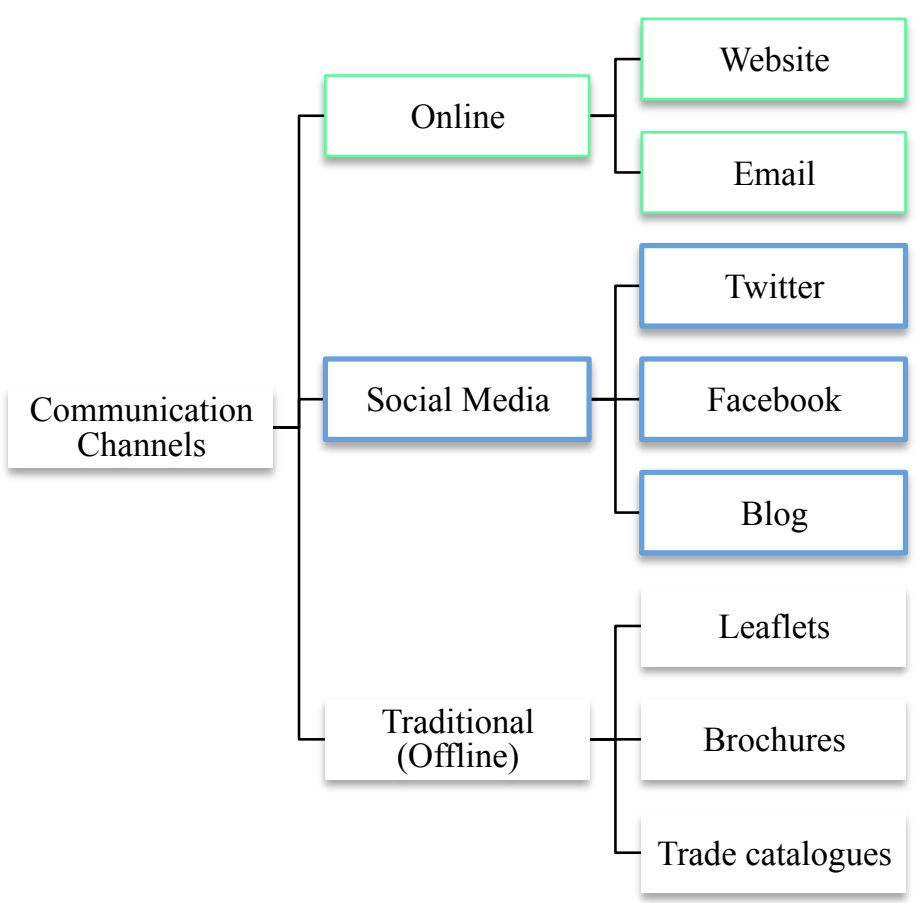


Focusing on the 'online' channels first, these micro-organizations utilize both email communication and a company website to broadcast their messages. Both of these 'platforms' only provide an opportunity for one-way communication that is directional in nature. OM2 highlights that "we normally just email people when we've got offers on, it's more for like advertising" (Is). Similar use can be observed in the other two microorganizations (SE). A reason why the owner-managers neither use emails for promoting their workshops, nor their international community engagement is the assumption that consumers seldom read emails and normally delete them straight away (OM3 Is). Thus, OM3 believes that if she needs to communicate something that is important to her and wants people to engage, sending an email is the least favored option (Is).

Organizations 1 and 2's website provides detailed information on their overall mission, vision and values and clearly highlights the fact that 'sustainability' is at the core of their business agenda (SE). Micro-organization 1 clearly states that they work together with "local suppliers" and try to build "long-term relationships with the community", whilst working with "upcycling and local fashion systems" (SE). On the other hand, micro-organization 2 emphasizes that they focus on a "green balance" that considers social and environmental aspects by producing locally in a "100\% sweatshop free environment" (SE). Both websites clearly communicate what their owner-managers believe to be key aspects of CSR: community involvement and fair and safe working conditions. Micro-organization 3's website is very basic and only provides the company's address - neither aspects of CSR nor sustainability are present on this platform. An explanation could be that due to being a co-operative, with designers and makers changing frequently, having a more detailed website would be too time consuming and hard to maintain.

\section{The role of social media in CSR communication}

Social media forms a vital part of the communication strategy of these microorganizations, as "it's massive! It's a great way to get in touch with people... who are interested in your brand and to get people who haven't heard of you to hear about you" (Is). Twitter, Facebook, and the company blogs all allow for dialogic communication, as 
anyone interested in the tweets and posts have the opportunity to directly respond to the messages sent. All three micro-organizations are extremely vocal on Twitter and Facebook, whilst only micro-organizations 1 and 2 regularly maintain their blogs. The owner-managers insist that they try to update all their social media channels regularly and rather than only posting promotional tweets, they also try to update consumers about their upcoming events (e.g. upcycling workshops), general noteworthy business news, trends in the industry, and responding to queries (SE; TF).

Focusing on the Twitterfeed analysis, it becomes apparent that although all three owner-managers report that they "tweet at least twice a day" (Is) the majority of tweets seem to be in irregular waves. The micro-organizations tweet approximately 20 times a day, if they have an upcoming event, and otherwise only once every two/three days. Looking at the content of these tweets more closely it can be seen that these microorganizations associate themselves with various hashtags, such as \#sustfash, \#ethical, and \#local, which fits with the overarching theme of sustainability and CSR. Yet, rather than broadcasting how these companies get involved in the local community and what events they are organizing, these tweets are predominantly promotional in nature:

Time for [Organization 1]'s back to school \& end of summer sale! \#sustfash (Tweeted: micro-organization 1)

Learning from the past with our new Make, Do \& Mend feature [...] \#sustfash \#fashion \#sustainability (Tweeted: micro-organization 1)

Made in the UK - (Organization 2) (company name) are delighted to be delivering our Fashion and Textile training here (Tweeted: micro-organization 2)

Bubble London Homegrown showcases labels that are designed and manufactured in the UK. Come and see us ([Organization 2]) on stand A40. We're completely Homegrown! (Tweeted: micro-organization 2)

There's still time to buy those last minute gifts! Get down to [Organization 3] lots of lovely, quirky, one-off pieces!! \#buylocal \#[city's name] (Tweeted: microorganization 3)

[Organization 3] is open today. Come in from the rain for some lovely handmade gifts \#localshopping (Tweeted: micro-organization 3)

Although these micro-organizations associate themselves with aspects of sustainability, 
only a minority of tweets communicate CSR activities that are taking place in the individual companies. The engagement rate on Twitter is low or even non-existent. The only dialogues that could be recorded throughout the three month period were of a private nature and lacked further stakeholder engagement. Thus, a key finding that emerges from the data is the fact that Twitter may not be used as effectively as it could be within these micro-organizations. Whilst they are broadcasting messages, whether of a promotional nature or to highlight any CSR activities, these are not received by the audience as an invite to engage. Rather than simply stating facts, it may be beneficial to pose questions and seek feedback from followers, which could lead to higher response rates and more support for their CSR activities.

The Facebook analysis showed similar results. Stakeholder engagement is limited and the micro-organizations do not utilize this platform to promote their CSR activities. OM1 indicates that "we want to be a kind of go to brand for not only you know buying clothes, but also for information, ideas and also because we wanna kind of really promote that... kind of do-it-yourself kind of grass roots activism... but we don't wanna get across too preachy... it's a fine balance” (Is). Thus, an explanation for why these micro-organizations do not actively promote CSR activities and issues of sustainability through their social media channels may be because they want to be more inclusive and encourage people to explore the brands and their values, rather than emphasizing CSR as their primary concern (Is; SE; TF).

The only social media channel that focuses on CSR activities within these microorganizations is the blog. OM1 states that she has created her blog so that "you can also learn how to do something to your own clothes, or find out how to... and come to our clothes swap and things like that", yet "the blog on the website, which is something we always... try to develop... unfortunately it's one of those things that always slides and we don't update it as much as we could" (Is). Similar findings could be observed in microorganization 3. Although OM1 and OM3 feel that the blogs are a good idea and would support them in promoting their community engagement, keeping them updated and maintaining them on a regular basis is too time intensive (Is). Contrarily, OM2 utilizes her blog to post regular updates on the company's relationship with the NGO and indicates what has been achieved with the profits they have made. OM2 further posts 
pictures and journal entries when she visits the site and specifies how donations have helped children and what happened to those that were previously featured. The blog receives quite a lot of attention, with consumers posting comments of support and sharing the entries on Twitter and Facebook.

These micro-organizations perceive online communication tools as vitally important to share information and broadcast their message to stakeholders ${ }^{62}$. Although stakeholders have an opportunity to engage with these micro-organizations on a variety of platforms, the overall response rate is low. Only micro-organization 2 seems to be able to attract stakeholder engagement through their blog entries, which provide further information on their CSR activities ${ }^{63}$. Various issues emerge from these observations: first, why do stakeholders only engage with the blog rather than with all social media platforms? A possible explanation could be that Twitter only allows for 134 characters to be written for any one post, thus reporting about CSR activities may be challenging, whilst Facebook is predominantly used for personal reasons rather than on a professional level $^{64}$. Second, the lack of control over content that is posted by third parties, as well as the amount of engagement from the side of the stakeholders provide challenges for these micro-organizations ${ }^{65,66}$.

\section{Conclusions}

Although social media and digital channels are central to micro-organizations to promote their brand message to a wider audience ${ }^{67}$, a clear line can be drawn between channels that are valuable for promotional purposes and those that can enhance the awareness of CSR activities. Providing links to CSR activities on the company website is essential, as stakeholders usually investigate a company's homepage at least once - either to purchase products or to gain more information about brands. Data indicate that blogs engage stakeholders, as images can be shared, stories told, and detailed information provided about any CSR activities. Due to the nature of Twitter and Facebook, the former with limited characters and the latter with its more personal purpose, neither seem to successfully engage stakeholders, nor be utilized by these micro-organizations to promote their CSR activities.

Dialogic communication that enhances stakeholder engagement is vital in today's 
business world; thus, finding a balance between pushing sales and providing information is key. These three micro-organizations lack a clear strategy to communicate their activities. Information is posted at random and without any clear purpose. Although all three are engaged in CSR activities, none promote them to their full potential, nor provide an opportunity for stakeholders to feedback back on how to enhance individual aspects. This has various practical implications: First, these micro-organizations need to ensure continuous maintenance of their individual channels in order to avoid spamming newsfeeds prior to an event, if they are normally only posting every other day. Digital platforms (e.g. Hootsuite) help to co-ordinate post by timing news releases and interlinking individual social media accounts. Second, communication experts could help to develop tailored communication strategies that fit the purpose of the individual microorganization, whilst providing support in using digital channels in a more engaging manner. The lack of a marketing/communication background within all three microorganizations leaves these owner-managers currently in a trial-and-error state that could be resolved by seeking advice from professionals. Third, within these microorganizations no social media or digital policy was communicated verbally or was evident in any documentation, which could lead to difficulties in the future, especially if these organizations are to grow into SMEs. Future research should investigate if CSR activities could be promoted better through introducing a digital media policy.

\section{References}

${ }^{1}$ Parveen, S. (2014). Rana Plaza factory collapse survivors struggle one year on, BBC [online], retrieved from: http://www.bbc.co.uk/news/world-asia-27107860, [accessed: 06/08/2014]

${ }^{2}$ Colleoni, E. (2013). CSR communication strategies for organizational legitimacy in social media. Corporate Communication: An International Journal, 18(2): 228-248.

${ }^{3}$ McPherson, S. (2014). Stylish and sustainable: How brands are getting it right. Forbes [online], retrieved: $\quad h \mathrm{http}: / / w w w . f o r b e s . c o m / s i t e s /$ susanmcpherson/2014/03/18/stylish-andsustainable-how-brands-are-getting-it-right/\#1c68737f2578, [accessed: 17/03/2016]

${ }^{4}$ Belz, F.-M., \& Peattie, K. (2012). Sustainability Marketing: A Global Perspective. $2^{\text {nd }}$ edition, John Wiley \& Sons Ltd.: Chichester, UK.

${ }^{5}$ Mintel (2015). The Ethical Consumer - UK- July 2015, Mintel: London, UK.

${ }^{6}$ EC (European Commission) (2002). Corporate Social Responsibility: A Business Contribution to Sustainable Development. COM (2002) 347 final, Brussels: Commission of the European Communities, Europa [online], retrieved: http:/eurlex.europa.eu/LexUriServ/LexUriServ.do?uri=COM:2002:0347:FIN:en:PDF, [accessed: $11 / 10 / 2011]$.

${ }^{7}$ White, A.L. (2006). Business Brief: Intangibles and CSR. BSR [online], retrieved: 
${ }^{8}$ Colleoni, op. cit.

http://bsr.org/reports/BSR_AW_Intangibles-CSR.pdf, [accessed: 19/07/2013].

${ }^{9}$ Chironga, M., Dhal, J., Goland, T. Pinshaw, G., \& Sonnekus, M. (2012). Micro-, small and medium-sized enterprises in emerging markets: how banks can grasp a $\$ 350$ billion opportunity. McKinsey \& Company [online], retrieved from: http://www.eflglobal.com/sites/default/files/knowledge_center/MSME-EmergingMarket-Banking-report.pdf, [accessed: 25/01/14].

${ }^{10}$ Esposito, A. (2013). Insights about integrated marketing communication in small-and mediumsized Italian enterprises. Business Systems Review, 2(1): 80-98.

${ }^{11}$ Pozniak, H. (2016). The only way is ethics. The Guardian, Your Guide to Postgraduate Study 22 March: 19

${ }^{12}$ Ward, M., \& Rhodes, C. 2014. Small businesses and the UK economy. UK Parliament [online]. Retrieved: www.parliament.uk/briefing-papers/sn06078.pdf, [accessed: 14/06/2014].

${ }^{13}$ WCED (1987). Our Common Future (The Brundtland Report), World Commission on Environment and Development, Oxford University Press: Oxford, UK.

${ }^{14}$ Palazzo, G., \& Scherer, G. (2006). Corporate legitimacy as deliberation: a communicative framework. Journal of Business Ethics, 66(1): 71-88.

${ }^{15} \mathrm{H} \& \mathrm{M}$ (2016). Conscious Fashion. H\&M [online], retrieved: http://about.hm.com/en/About/sustainability/commitments/conscious-fashion.html, [accessed: 17/03/2016]

${ }^{16}$ Toms (2016). One of One. Toms [online]. Retrieved: http://www.toms.co.uk, [accessed: 17/03/2016].

${ }^{17}$ Colleoni, op. cit.

${ }^{18}$ Morsing, M., Schultz, M., \& Nielsen, K.U. (2008). The 'Catch 22' of communicating CSR: findings from a Danish study. Journal of Marketing Communications, 14(2): 97-111.

${ }^{19}$ Colleoni, op. cit.

${ }^{20}$ Lee, K., Oh, W.-Y., \& Kim, N. (2013). Social media for socially responsible firms: analysis of Fortune 500's Twitter profiles and their CSR/CSIR ratings. Journal of Business Ethics, 118(4): 791-806.

${ }^{21}$ Mittelstaedt, J.D., Schultz II, C.J., Kilbourne, W.E., \& Peterson, M. (2014). Sustainability as megatrend: Two schools of macromarketing thought. Journal of Macromarketing, 34(3): 253-264.

${ }^{22}$ McWilliams, A., \& Siegel, D.S. (2001). Corporate social responsibility: A theory of the firm perspective. Academy of Management Review, 26(1): 117-127.

${ }^{23}$ Crook, C. (2005). Special Report: Corporate Social Responsibility - The Good Company. Economist [online], 20 January 2005, retrieved: http://www.economist.com/node/3555212, [accessed: 11/07/2015].

${ }^{24}$ Porter, M.E., \& Kramer, M.R. (2006). Strategy and Society: The link between competitive advantage and corporate social responsibility. Harvard Business Review, 84(12): 78-92

${ }^{25}$ Sheehan, M. (2013). Corporate Citizenship. Leader to Leader, 70: 26-31.

${ }^{26}$ Porter \& Kramer, op. cit.

${ }^{27}$ Porter \& Kramer, op. cit.

${ }^{28}$ Belz \& Peattie, op. cit.

${ }^{29}$ Franklin, D. (2008). Just Good Business. Economist [online]. $17^{\text {th }}$ January 2008, retrieved: http://www.economist.com/node/10491077, [accessed: 11/10/2011].

${ }^{30}$ Morsing, M., \& Schultz, M. (2006). Corporate Social Responsibility communication: stakeholder information, response, and involvement strategies. Business Ethics, 15(4): 323-338 
${ }^{31}$ Mangold, W.G., \& Faulds, D.J. (2009). Social Media: the new hybrid element of the promotional mix. Business Horizons, 52(4): 357-365

${ }^{32}$ Kietzmann, J.H., Hermkens, K., McCarthy, I.P., \& Silvestre, B.S. (2011). Social media? Get serious! Understanding the functional building blocks of social media. Business Horizons, 54: 241-251.

${ }^{33}$ De Bakker, F.G.A., \& Hellsten, I. (2013). Capturing online presence: hyperlinks and semantic networks in activist group websites on corporate social responsibility. Journal of Business Ethics, 118: 807-823.

${ }^{34}$ De Bakker \& Hellsten, op. cit.

${ }^{35}$ Hoegg, R., Martignoni, R., Meckel, M., \& Stanoevska-Slabeva, K. (2006). Overview of Business Models for Web 2.0 Communities. GeNeMe, Dreseden, pp. 23-37.

${ }^{36}$ Wilson, S.M., \& Peterson, L.C. (2002). The anthropology of online communities. Annual Review of Anthropology, 31(1): 449-467.

${ }^{37}$ Foster, D., \& Jonker, J. (2005). Stakeholder relationships: the dialogue of engagement. Corporate Governance, 5(5): 51-57.

${ }^{38}$ Fieseler, C., \& Fleck, M. (2013). The pursuit of empowerment through social media: structural social capital dynamics in CSR-blogging. Journal of Business Ethics, 118: 759-775.

${ }^{39}$ Dellarocas, C. (2003). The digitization of word of mouth: promise and challenges of online feedback mechanisms. Management Science, 49(10): 1407-1424.

${ }^{40}$ Fieseler \& Fleck, op. cit.

${ }^{41}$ Colleoni, op. cit.

${ }^{42}$ Freeman, E., \& Moutchnik, A. (2013). Stakeholder management and CSR: questions and answers. Uwf UmweltWirtschaftsForum. Berlin: Springer.

${ }^{43}$ Kaplan, A.M., \& Haenlein, M. (2010). Users of the world, unite! The challenges and opportunities of social media. Business Horizons, 53(1): 59-68.

${ }^{44}$ Fieseler \& Fleck, op. cit.

${ }^{45}$ Lee et al, op. cit.

${ }^{46}$ Kaplan, A. M., \& Haenlein, M. (2011). Two hearts in three-quarter time: How to waltz the social media/viral marketing dance. Business Horizons, 54(3), 253-263.

${ }^{47}$ Kietzmann, J., \& Canhoto, A. (2013). Bittersweet! Understanding and managing electronic word of mouth. Journal of Public Affairs, 13(2): 146-159.

${ }^{48}$ De Bakker \& Hellsten, op. cit.

${ }^{49}$ Yin, R.K. (2003). Case Study Research: design and method. $3^{\text {rd }}$ edition, SAGE Publications Ltd.: Thousand Oaks, CA

${ }^{50} \mathrm{EC}$, op. cit.

${ }^{51}$ Easterby-Smith, M., Thorpe, R., \& Jackson, P. (2008). Management Research. $3^{\text {rd }}$ edition, SAGE Publications: London, UK.

${ }^{52}$ Fassin, Y., Van Rossem, A., \& Buelens, M. (2011). Small-business owner-managers perceptions of business ethics and CSR-related concepts. Journal of Business Ethics, 98(3): 425-453.

${ }^{53}$ BBC Democracy (2013). Peers urge support for sustainable fashion. $20^{\text {th }}$ March 2013, BBC [online], retrieved: http://www.bbc.co.uk/democracylive/house-of-lords-21850300, [accessed: 05/07/2013].

${ }^{54}$ Esposito, op. cit.

${ }^{55}$ McWilliams \& Siegel, op. cit.

${ }^{56}$ McWilliams \& Siegel, op. cit.

${ }^{57}$ Sloan, P. (2009). Redefining stakeholder engagement from control to collaboration. Journal of Corporate Citizenship, 36: 25-40.

${ }^{58}$ Sheehan, op. cit. 
${ }^{59}$ Crook, op. cit.

${ }^{60}$ Porter \& Kramer, op. cit.

${ }^{61} \mathrm{McW}$ illiams \& Siegel, op. cit.

${ }^{62}$ Hoegg et al, op. cit.

${ }^{63}$ Fieseler \& Fleck, op. cit.

${ }^{64}$ Freeman \& Moutchnik, op. cit.

${ }^{65}$ Kaplan \& Haenlein, op. cit.

${ }^{66}$ Kietzmann \& Canhoto, op. cit.

${ }^{67}$ Lee et al, op. cit. 